\title{
Scale of Personal Problems in Everyday Life: Conceptual Justification and Psychometric Development
}

\author{
Konstantin K. Karpinskii ${ }^{{ }^{*}}$, Natal'ya V. Kisel'nikova ${ }^{2}$ \\ 'Yanka Kupala State University of Grodno, Grodno, Belarus \\ ${ }^{2}$ Psychological Institute, Russian Academy of Education, Moscow, Russian Federation \\ *Corresponding author. E-mail: karpkostia@tut.by
}

\begin{abstract}
Introduction. Theoretical and methodological issues of psychology of personal problem solving in everyday life have been underrepresented in Russian research literature. For the first time, the authors develop, pilot-test, and validate a new technique for diagnosing personal problems of everyday life.
\end{abstract}

Methods. The sample was comprised of 506 individual participants (aged 17-67 years) from general population and of 43 patients of the psycho-neurological department and the department of borderline states (aged 18-50 years). The study used the following techniques for construct validation of the pilot version of the Scale: (a) Life Satisfaction Scale; (b) Positive and Negative Affect Scale; (c) Five-Factor Personality Inventory; (d) Life Orientation Test (Russian modification); and (e) Hardiness Survey (Russian modification).

Results and Discussion. This section (a) describes the procedure of developing the Scale and eliminating non-valid items, (b) examines the factor structure of the questionnaire, (c) determines its construct, structural, and differential validity, and (d) discusses the results of studying age, gender, social, and demographic differences in the general level of problematization of life and the manifestation of specific types of everyday problems. The authors compared the findings obtained in pilot testing with those described in previous studies and demonstrated their similarity. The study provides diagnostic norms for the Scale scores. The proposed technique has great potential for further research (collecting empirical data in various subject areas of psychology) and psychodiagnostic (supporting the consultative and psychotherapeutic process and clinical practice) applications.

Conclusion. The authors draw the conclusion that the developed technique manifests relevant measurement properties and can be recommended for use in psychological research and practice. Further psychometric development of the Scale will involve determining test-retest reliability, assessing the impact of social desirability on the results, as well as differentiating and specifying test norms on larger samples. 


\section{Keywords}

personality, personal problems, dispositional determination, five-factor model, big five, psychology of everyday life, everyday problems, psychodiagnostics, questionnaire, validation

\section{Highlights}

- An original Russian technique for diagnosing the degree of personal problems in everyday life is developed.

- The technique is a multi-dimensional standardized questionnaire (scale) and manifests relevant psychometric properties - namely, high reliability and structural, convergent, differential, and criterion validity.

- The questionnaire can be recommended for further research (collecting empirical data in various subject areas of psychology) and psychodiagnostic (supporting the consultative and psychotherapeutic process and clinical practice) applications.

\section{For citation}

Karpinskii K. K., Kisel'nikova N. V. Scale of Personal Problems in Everyday Life: Conceptual Justification and Psychometric Development. Rossiiskii psikhologicheskii zhurnal - Russian Psychological Journal, 2018, Thematic Issue 1 (Vol. 15, no. 2/1), pp. 38-56. DOI: 10.21702/ rpj.2018.2.1.3

Original manuscript received 05.09.2018

\section{Introduction}

One of the actual trends characterizing the vector of social and humanitarian knowledge movement is expressed in the shift of research focus to ontology and phenomenology of everyday life as day-to-day current reality of human life $[1,2,3]$. The emphasis on everyday life in the field of psychological analysis suggests paying closer attention to such phenomena, which previously lied "in the shadow" of mental phenomena, arising in the mode of non-everyday human existence. In particular, this trend actualizes the request for the study of personal difficulties and problems woven into the "fabric" of everyday human life.

The methodological development of this problem is conducted in line with the dispositional approach and based on the five-factor model of personal traits ("Big five"), where everyday personal problems become the "units" of psychological analysis of personal dispositions. Theoretical prerequisites for such understanding of personal problems are formulated during the discussion of the criterion validity of the five-factor model of personality. Based on the idea that a particular disposition carries a predisposition to a specific form of maladjustment, personality disorders and disorders have traditionally been chosen as the criteria for validation $[4,5,6,7,8]$. 
Despite the productivity of this approach, there are doubts that the personal problems of the psychopathological level can be an adequate unit of analysis of the normal personality in everyday life. In this regard, the term "personalityrelated problems" was introduced relatively recently to refer to the psychological difficulties of a person in everyday life, which are generated by polar personal dispositions [7]. There are single studies aimed, firstly, at revealing the mechanisms and regularities of the relationship of personal problems with individual dispositions of personality $[9,10]$, and secondly, at building a taxonomy of personal problems and designing psychometrically verified methods of their diagnosis $[8,11,12,13,11]$. As part of solving the second task, the following methods were developed: Personal Problems Checklist for Adults (PPCA) and Children (PPCC) [11, 14], The Multi-Context Problems Checklist (MCPC) [13], Inventory of Interpersonal Problems (IIP) [15].

In Russian research literature there is absence of both studies and diagnostic tools on this subject. In this regard, the aim of the study was the development, testing and validation of a new method for assessing personal problems of everyday life.

\section{Methods}

The questionnaire was developed on a sample of 506 respondents aged from 17 to 67 years old $(M=34 \pm 9)$, 281 women, 225 men. The sample is characterized by high variability of socio-demographic and status-role characteristics of the subjects. It consists of people with different levels of education, marital status, parental and labor status.

In order to check the criteria validity, there was an additional examination of the clinical sample consisting of 43 patients ( 30 women and 13 men from 18 to 50 years old ( $M=32 \pm 9$ years) of the Psychoneurological Department and the Department of Borderline Neuropsychological States № 3 in Grodno. All respondents had diagnoses related to the category of borderline neuropsychiatric disorders (F4 - "Neurotic, stress - related and somatoform disorders", F5 - "Behavioral syndromes associated with physiological disturbances and physical factors", F6 - "Disorders of adult personality and behavior" according to ICD-10).

Pilot version of the questionnaire was presented to the subjects in a set of techniques for construct validation: "Satisfaction with Life Scale", SWLS, by E. Diener in the adaptation of E. N. Aspen and D. A. Leontiev [16], "Positive Affect and Negative Affect Scale", PANAS, in the adaptation of E. N. Aspen [17], "Five Personality Factors Questionnaire", 5PFQ, in the adaptation of A. B. Khromova [18], "Life Orientation Test", LOTm by M. Shayera and C. Carver in the adaptation of the E. O. Gordeeva [19], "Hardiness Survey» by S. Maddi in adaptation of D. Leontiev and E. I. Rasskazova [20]. 


\section{Results and Discussion}

The units of the stimulus material of the Scale are represented by the tasks that people set and solve in everyday life. The list of tasks was formed by inductive-deductive method: part of the tasks was extracted from the minutes of consultative conversations, the other part of the tasks was identified by analyzing the stimulus material of existing diagnostic techniques, primarily modern foreign analogues. The content validity of the questionnaire was ensured by the representativeness of the stimulus material in relation to the typical tasks of everyday life of the subjects. The primary version of the questionnaire covered 75 incentive tasks. In accordance with the instructions, the subject must assess the extent to which the solution of each problem is difficult for him, in accord with the four-point Likert scale.

\section{Factor structure and structural validity of the questionnaire}

The internal structure of the questionnaire was carried out with the help of factor analysis on a 75-point intercorrelation matrix. Factorization was carried out by the maximum likelihood estimation followed by oblique Promax-rotation of the factor structure; the critical value of the factor load was assumed to be 0.30 . Of the possible alternatives, the most successful one was the seven-factor solution, which explains $64 \%$ of the variance of variables (Table 1) and, according to the results of confirmatory factor analysis, is characterized by a satisfactory level of structural compliance $\left(\chi^{2}=4260,08, d f=2271, p=0,001, \chi^{2} / d f=1,87 ; \operatorname{RMSEA}=0,05\right.$, $\mathrm{SRMR}=0,06, \mathrm{CFI}=0,95, \mathrm{TLI}=0,95)$.

Table 1. Results of factor analysis of the pilot version of the questionnaire

\begin{tabular}{|l|c|c|c|}
\hline $\begin{array}{l}\text { Factors (scales of } \\
\text { the questionnaire) }\end{array}$ & Point numbers and load & $\begin{array}{l}\text { Points } \\
\text { discriminativity } \\
\text { coefficient }\end{array}$ & a-Cronbach \\
\hline $\begin{array}{l}\text { Factor I "Problems of } \\
\text { self-assertion in inter- } \\
\text { personal relations" }\end{array}$ & $\begin{array}{l}15(0,33), 17(0,58), \\
36(0,31), 40(0,51),\end{array}$ & $0,37-0,63$ & 0,81 \\
& $42(0,59), 48(0,42)$, & & \\
& $53(0,40)$ & & \\
\hline Factor II "Problems of & $1(0,42), 3(0,34), 7(0,44)$, & $0,40-0,64$ & \\
personal regulation & $11(0,51), 14(0,33)$, & & \\
of the life time" & $16(0,31), 30(0,61)$, & & \\
& $31(0,52), 33(0,45)$, & & \\
& $45(0,68), 46(0,33)$, & & \\
& $56(0,41)$ & & \\
\hline
\end{tabular}




\begin{tabular}{|c|c|c|c|}
\hline $\begin{array}{l}\text { Factors (scales of } \\
\text { the questionnaire) }\end{array}$ & Point numbers and load & $\begin{array}{l}\text { Points } \\
\text { discriminativity } \\
\text { coefficient }\end{array}$ & a-Cronbach \\
\hline $\begin{array}{l}\text { Factor III "Problems } \\
\text { of self-consciousness" }\end{array}$ & $\begin{array}{c}2(0,56), 5(0,55), 21(0,52), \\
25(0,59), 37(0,45), \\
43(0,68), 51(0,72), \\
54(0,55)\end{array}$ & $0,32-0,57$ & 0,77 \\
\hline $\begin{array}{l}\text { Factor IV "Moral } \\
\text { problems of } \\
\text { personality" }\end{array}$ & $\begin{array}{c}6(0,47), 8(0,48), 12(0,41), \\
13(0,47), 24(0,53), \\
28(0,38), 32(0,44), \\
34(0,77), 41(0,64), \\
44(0,56)\end{array}$ & $0,32-0,55$ & 0,78 \\
\hline $\begin{array}{l}\text { Factor V "Problems } \\
\text { of socio-psycholog- } \\
\text { ical adaptation of } \\
\text { personality" }\end{array}$ & $\begin{array}{l}19(0,62), 38(0,55) \\
39(0,37), 52(0,63)\end{array}$ & $0,55-0,67$ & 0,80 \\
\hline $\begin{array}{l}\text { Factor VI "Problems } \\
\text { of coping and self- } \\
\text { regulation in difficult } \\
\text { life situations" }\end{array}$ & $\begin{array}{l}18(0,31), 20(0,38), \\
27(0,55), 29(0,45), \\
35(0,43), 47(0,46), \\
49(0,39), 50(0,41), \\
55(0,50), 57(0,54)\end{array}$ & $0,44-0,60$ & 0,80 \\
\hline $\begin{array}{l}\text { Factor VII "Cognitive } \\
\text { problems of } \\
\text { personality" }\end{array}$ & $\begin{array}{c}4(0,54), 9(0,37), 10(0,40) \\
23(0,57)\end{array}$ & $0,32-0,56$ & 0,71 \\
\hline
\end{tabular}


The first factor $(21,1 \%$ of variance), called "Problems of self-assertion in interpersonal relations", is represented mainly by communicative tasks, the common feature of which is the need to develop and defend their own position in spite of the opposition of the social environment. The second factor (15,6\% of variance) is represented by the tasks of temporal organization of behavior and life activity both on a situational basis and in the course of the whole life and is defined as "Problems of personal regulation of the life time". The third factor (11,3\% of variance) integrates items that reflect reflexive tasks aimed mainly at personal self-understanding, self-evaluation and self-change. It was called "Problems of self-consciousness». The fourth factor ( $8 \%$ of variance) encompasses the points reflecting the tasks of moral self-regulation - the way a person constructs their behavior, activity and communication in accordance with the norms of universal ethics and morality. This factor was designated as "Moral problems of personality". The fifth factor $(3,04 \%$ of variance) is composed of items corresponding to the tasks of socio-psychological adaptation to changing social conditions, first of all, unfamiliar partners in communication and new membership groups, and is designated as "Problems of socio-psychological adaptation of personality". The sixth factor $(2,65 \%$ of variance) is formed from the points describing the tasks of self-regulation of negative emotional and functional states in difficult life situations, and is called "Problems of coping and self-regulation in difficult life situations". The seventh factor (2,31\% of variance) consists of points reflecting cognitive tasks solved in the course of everyday life: attentional, mnestic and mental. It received the name "Cognitive problems of the personality». 18 points that did not gain sufficient load were eliminated. The final version of the tool contains 57 points divided into 7 sub-scales.

Further, the focus of the study shifted onto the question of the integral diagnostic index reflecting the general level of problematization of daily life of the respondent. To this end, a factor analysis was carried out using the maximum likelihood estimation on the subscale intercorrelation matrix (Table 2). Sub-scales of the questionnaire formed one factor explaining $59 \%$ of variability of variables and significantly loaded with all types of personal problems of everyday life. Confirmatory factor analysis confirms the validity of the allocation of the total latent factor $\left(\chi^{2}=21,7, \mathrm{df}=14, \mathrm{p}=0,01\right.$, $\left.\chi^{2} / \mathrm{df}=1,55 ; \mathrm{RMSEA}=0,046, \mathrm{SRMR}=0,05, \mathrm{CFI}=0,99, \mathrm{TLI}=0,985\right)$. The values of the point-integral scale correlations indicate an appropriate level of discrimination of points $(0,27-0,61)$, and the scale as a whole is characterized by high consistency $(a=0,94)$. 
Table 2. Intercorrelation and the results of the secondary factorization of the questionnaire's subscales

\begin{tabular}{|c|c|c|c|c|c|c|c|}
\hline $\begin{array}{l}\text { Subscales of the } \\
\text { questionnaire }\end{array}$ & SS 1 & SS 2 & SS 3 & SS 4 & SS 5 & SS 6 & $\begin{array}{l}\text { Factor } \\
\text { loads }\end{array}$ \\
\hline $\begin{array}{l}\text { SS 1: Problems of self-assertion } \\
\text { in interpersonal relations }\end{array}$ & & & & & & & 0,77 \\
\hline $\begin{array}{l}\text { SS 2: Problems of personal } \\
\text { regulation of the life time }\end{array}$ & 0,51 & & & & & & 0,79 \\
\hline $\begin{array}{l}\text { SS 3: Problems of } \\
\text { self-consciousness }\end{array}$ & 0,57 & 0,61 & & & & & 0,82 \\
\hline $\begin{array}{l}\text { SS 4: Moral problems of } \\
\text { personality }\end{array}$ & 0,41 & 0,50 & 0,62 & & & & 0,74 \\
\hline $\begin{array}{l}\text { SS 5: Problems of socio- } \\
\text { psychological adaptation of } \\
\text { personality }\end{array}$ & 0,55 & 0,43 & 0,44 & 0,44 & & & 0,70 \\
\hline $\begin{array}{l}\text { SS 6: Problems of coping and } \\
\text { self-regulation in difficult life } \\
\text { situations }\end{array}$ & 0,58 & 0,59 & 0,58 & 0,53 & 0,53 & & 0,80 \\
\hline $\begin{array}{l}\text { SS 7: Cognitive problems of } \\
\text { personality }\end{array}$ & 0,48 & 0,53 & 0,51 & 0,48 & 0,42 & 0,46 & 0,72 \\
\hline
\end{tabular}

Gender, age and socio-demographic differences.

Gender differences in the severity of personal problems of everyday life were assessed by the two-part Student's t-test. The revealed differences, however, are characterized by the small size of the effect (Cohen's $d<0,50$ ) and in practice have no significant value. Also, the indicators of the questionnaire almost do not correlate with the age of the subjects. The only statistically significant trend is that with age people tend to solve the problem of self-regulation of life time easier $(r=-0,17, p<0,001)$. 
With the help of univariate analysis of variance significant differences between subjects with different levels of education were found. They concern self-regulation of life time $\left(F=3,34, p=0,019, \eta^{2}=0,02\right)$ and cognitive problems $(F=3,84$, $p=0,01, \eta^{2}=0,02$ ), as well as the general level of problematization of everyday life $\left(F=2,68, p=0,04, \eta^{2}=0,015\right)$. With the growth of the educational level, the subjective difficulty of solving these types of everyday problems and the tendency to problematize everyday life decreases. Given the small size of the effect, these differences may not be pronounced. More accentuated differences can be seen in the comparison of respondents with different marital status: single and married. As follows from the Table 3 data, single people are characterized by a greater tension of self-assertion problems in interpersonal relationships, self-regulation of life time, social and psychological adaptation to new life circumstances, coping and self-control in difficult situations, and their daily life is generally perceived as more difficult and problematic. However, based on the effect size (Cohen's $d=0,24 \sim 0,44)$, statistically significant differences may not be as significant.

Table 3. The results of the analysis of difference related to marital status

\begin{tabular}{|l|c|c|c|c|c|c|c|}
\hline \multirow{2}{*}{ Questionnaire indicators } & \multicolumn{2}{|c|}{ Single } & \multicolumn{2}{c|}{ Married } & t & d & $\boldsymbol{\eta}^{2}$ \\
\cline { 2 - 7 } & $\mathbf{M}$ & $\boldsymbol{\sigma}$ & $\mathbf{M}$ & $\boldsymbol{\sigma}$ & & \\
\hline $\begin{array}{l}\text { Problems of self-assertion in } \\
\text { interpersonal relations }\end{array}$ & 16,49 & 4,94 & 15,42 & 3,94 & $2,04^{*}$ & 0,24 & 0,007 \\
\hline $\begin{array}{l}\text { Problems of personal } \\
\text { regulation of the life time }\end{array}$ & 23,10 & 6,42 & 20,51 & 5,24 & $3,77^{* * *}$ & 0,44 & 0,025 \\
\hline $\begin{array}{l}\text { Problems of } \\
\text { self-consciousness }\end{array}$ & 13,45 & 4,04 & 12,80 & 2,92 & 1,52 & - & - \\
\hline $\begin{array}{l}\text { Moral problems of personality } \\
\text { Problems of socio- }\end{array}$ & 16,13 & 4,50 & 15,40 & 3,51 & 1,53 & - & - \\
\hline $\begin{array}{l}\text { psychological adaptation of } \\
\text { personality }\end{array}$ & 7,43 & 2,94 & 6,65 & 2,18 & $2,50^{*}$ & 0,30 & 0,011 \\
\hline $\begin{array}{l}\text { Problems of coping and } \\
\text { self-regulation in different life } \\
\text { situations }\end{array}$ & 22,46 & 6,25 & 21,10 & 4,79 & $2,06^{*}$ & 0,24 & 0,007 \\
\hline $\begin{array}{l}\text { Cognitive problems of } \\
\text { personality }\end{array}$ & 7,74 & 2,45 & 7,01 & 2,20 & $2,77^{* *}$ & 0,31 & 0,014 \\
\hline $\begin{array}{l}\text { General level of } \\
\text { problematization of everyday } \\
\text { life }\end{array}$ & 106,80 & 24,80 & 98,89 & 16,86 & $3,05^{* *}$ & 0,37 & 0,016 \\
\hline
\end{tabular}


Based on the data in Table 4, it can be argued that active employment provides a person with resources to facilitate everyday tasks. Employed people have a tendency to cope with the tasks of personal regulation of life time, selfunderstanding and self-assessment easier. Students who are systematically involved in mental activity, report the greater difficulty of cognitive tasks, which are associated with the assimilation and processing of a large amount of new information.

Table 4. The results of the analysis of difference related to the employment status

\begin{tabular}{|l|c|c|c|c|c|c|c|}
\hline \multirow{2}{*}{ Questionnaire indicators } & \multicolumn{2}{|c|}{$\begin{array}{c}\text { Employed } \\
\text { participants }\end{array}$} & \multicolumn{2}{|c|}{ Students } & T & d & $\boldsymbol{\eta}^{2}$ \\
\cline { 2 - 7 } & $\mathbf{M}$ & $\boldsymbol{\sigma}$ & $\mathbf{M}$ & $\boldsymbol{\sigma}$ & & \\
\hline $\begin{array}{l}\text { Problems of self-assertion } \\
\text { in interpersonal relations }\end{array}$ & 15,96 & 4,65 & 16,52 & 4,87 & 1,33 & - & - \\
\hline $\begin{array}{l}\text { Problems of personal } \\
\text { regulations of the life } \\
\text { time }\end{array}$ & 21,85 & 6,18 & 23,17 & 6,32 & $2,44^{*}$ & 0,21 & 0,010 \\
\hline $\begin{array}{l}\text { Problems of } \\
\text { self-consciousness }\end{array}$ & 12,92 & 3,49 & 13,61 & 4,08 & $2,07^{*}$ & 0,18 & 0,007 \\
\hline $\begin{array}{l}\text { Moral problems of } \\
\text { personality }\end{array}$ & 15,60 & 4,13 & 16,27 & 4,46 & 1,78 & - & - \\
\hline $\begin{array}{l}\text { Problems of socio- } \\
\text { psychological } \\
\text { adaptation of } \\
\text { personality }\end{array}$ & 7,09 & 2,64 & 7,42 & 2,95 & 1,34 & - & - \\
\hline $\begin{array}{l}\text { Problems of coping and } \\
\text { self-regulation in difficult } \\
\text { life situations }\end{array}$ & 21,70 & 5,86 & 22,57 & 6,12 & 1,66 & - & - \\
\hline $\begin{array}{l}\text { Cognitive problems of } \\
\text { personality }\end{array}$ & 7,32 & 2,30 & 7,80 & 2,48 & $2,30^{*}$ & 0,20 & 0,009 \\
\hline $\begin{array}{l}\text { General level of } \\
\text { problematization of } \\
\text { everyday life }\end{array}$ & 102,47 & 22,05 & 107,39 & 24,68 & $2,40^{*}$ & 0,21 & 0,010 \\
\hline
\end{tabular}

The size of ETA-squared effect $\left(\eta^{2}\right)$, describing the share of intergroup variance associated with an independent (grouping) status variable in the total variance of the trait, was calculated for comparative assessment of the magnitude of status differences. The differences related to gender and marital status are most 
pronounced, accounting for 3,9 per cent and 2,5 per cent, respectively, of the diagnostic variance.

The General conclusion is that during adolescence and adulthood, as the social status and roles change, the individual acquires and accumulates a variety of resources that increase his competence in solving everyday life problems. This is manifested in a decrease in the level of subjective problematization of these tasks.

\section{Construct validity of the questionnaire}

The construct validization of the tool was carried out in the context of the assessment of convergent and discriminant validity. As criteria methods we used questionnaires diagnosing the intensity of individual psychological characteristics of the personality, which, as evidenced by the results of previous studies, serve as predictors of effective coping with both critical situations and with everyday life difficulties [20,21, 22]. In addition, for validization the questionnaire we also employed the variables that represent negative consequences of the problematization of everyday life, i.e. subjective well-being of the individual and its components: life satisfaction, as well as positive and negative affect [23, $24,25]$. Validitation test of the hypotheses was carried out with the help of Pearson's (Tables 5 and 6):

Table 5. The results of the correlation analysis of the «Big Five» variables and components of subjective well-being

\begin{tabular}{|c|c|c|c|c|c|c|c|c|c|c|c|c|c|c|c|}
\hline \multirow{2}{*}{$\begin{array}{l}\text { Sub- } \\
\text { scales } \\
\text { of the } \\
\text { ques- } \\
\text { tion- } \\
\text { naire } \\
\end{array}$} & \multicolumn{3}{|c|}{$\begin{array}{l}\text { Subjective } \\
\text { well-being }\end{array}$} & \multicolumn{3}{|c|}{$\begin{array}{l}\text { Dispositional } \\
\text { optimism }\end{array}$} & \multicolumn{4}{|c|}{ Resilience } & \multicolumn{5}{|c|}{ Big Five } \\
\hline & LS & PA & NA & PE & $\mathrm{NE}$ & DO & 1 & C & RA & GR & $E$ & A & $C$ & N & 0 \\
\hline $\begin{array}{l}\text { Prob- } \\
\text { lems of } \\
\text { self- } \\
\text { asser- } \\
\text { tion }\end{array}$ & $-0,12$ & $-0,23$ & 0,16 & $-0,08$ & 0,16 & $-0,15$ & $-0,28$ & $-0,33$ & $-0,19$ & $-0,34$ & $-0,25$ & 0,01 & $-0,25$ & 0,29 & $-0,11$ \\
\hline $\begin{array}{l}\text { Prob- } \\
\text { lems } \\
\text { of time } \\
\text { regula- } \\
\text { tion }\end{array}$ & $-0,29$ & $-0,27$ & 0,19 & $-0,12$ & 0,15 & $-0,20$ & $-0,46$ & $-0,46$ & $-0,22$ & $-0,48$ & $-0,18$ & $-0,22$ & $-0,53$ & 0,24 & $-0,05$ \\
\hline
\end{tabular}




\begin{tabular}{|c|c|c|c|c|c|c|c|c|c|c|c|c|c|c|c|}
\hline \multirow{2}{*}{$\begin{array}{l}\text { Sub- } \\
\text { scales } \\
\text { of the } \\
\text { ques- } \\
\text { tion- } \\
\text { naire }\end{array}$} & \multicolumn{3}{|c|}{$\begin{array}{l}\text { Subjective } \\
\text { well-being }\end{array}$} & \multicolumn{3}{|c|}{$\begin{array}{c}\text { Dispositional } \\
\text { optimism }\end{array}$} & \multicolumn{4}{|c|}{ Resilience } & \multicolumn{5}{|c|}{ Big Five } \\
\hline & LS & PA & NA & PE & $\mathrm{NE}$ & DO & 1 & C & RA & GR & E & A & C & $\mathbf{N}$ & 0 \\
\hline $\begin{array}{l}\text { Prob- } \\
\text { lems of } \\
\text { self- } \\
\text { cons- } \\
\text { cio- } \\
\text { usness }\end{array}$ & $-0,18$ & $-0,26$ & 0,18 & $-0,08$ & 0,15 & $-0,27$ & $-0,29$ & $-0,27$ & $-0,12$ & $-0,27$ & $-0,16$ & $-0,24$ & $-0,34$ & 0,24 & $-0,17$ \\
\hline $\begin{array}{l}\text { Moral } \\
\text { prob- } \\
\text { lems }\end{array}$ & $-0,12$ & $-0,20$ & 0,15 & $-0,14$ & 0,21 & $-0,31$ & $-0,32$ & $-0,29$ & $-0,21$ & $-0,32$ & $-0,16$ & $-0,44$ & $-0,34$ & 0,15 & $-0,21$ \\
\hline $\begin{array}{l}\text { Prob- } \\
\text { lems } \\
\text { of S-P } \\
\text { adap- } \\
\text { tation }\end{array}$ & $-0,14$ & $-0,23$ & 0,11 & $-0,17$ & 0,14 & $-0,23$ & $-0,44$ & $-0,42$ & $-0,33$ & $-0,47$ & $-0,45$ & $-0,20$ & $-0,22$ & 0,24 & $-0,15$ \\
\hline $\begin{array}{l}\text { Prob- } \\
\text { lems of } \\
\text { coping } \\
\text { and } \\
\text { self- } \\
\text { regu- } \\
\text { lation } \\
\text { in DLS }\end{array}$ & $-0,30$ & $-0,32$ & 0,25 & $-0,32$ & 0,15 & $-0,21$ & $-0,43$ & $-0,49$ & $-0,36$ & $-0,51$ & $-0,27$ & $-0,17$ & $-0,30$ & 0,54 & $-0,07$ \\
\hline
\end{tabular}




\begin{tabular}{|c|c|c|c|c|c|c|c|c|c|c|c|c|c|c|c|}
\hline \multirow{2}{*}{$\begin{array}{l}\text { Sub- } \\
\text { scales } \\
\text { of the } \\
\text { ques- } \\
\text { tion- } \\
\text { naire }\end{array}$} & \multicolumn{3}{|c|}{$\begin{array}{l}\text { Subjective } \\
\text { well-being }\end{array}$} & \multicolumn{3}{|c|}{$\begin{array}{l}\text { Dispositional } \\
\text { optimism }\end{array}$} & \multicolumn{4}{|c|}{ Resilience } & \multicolumn{5}{|c|}{ Big Five } \\
\hline & LS & PA & NA & PE & NE & DO & I & C & RA & GR & $\mathbf{E}$ & A & C & $\mathbf{N}$ & 0 \\
\hline $\begin{array}{l}\text { Cog- } \\
\text { nitive } \\
\text { prob- } \\
\text { lems }\end{array}$ & $-0,10$ & $-0,20$ & 0,09 & $-0,12$ & 0,22 & $-0,22$ & $-0,43$ & $-0,35$ & $-0,22$ & $-0,41$ & $-0,21$ & $-0,18$ & $-0,27$ & 0,09 & $-0,15$ \\
\hline $\begin{array}{l}\text { Total } \\
\text { score }\end{array}$ & $-0,25$ & $-0,33$ & 0,23 & $-0,19$ & 0,21 & $-0,28$ & $-0,47$ & $-0,47$ & $-0,29$ & $-0,50$ & $-0,29$ & $-0,27$ & $-0,44$ & 0,36 & $-0,15$ \\
\hline Notes: & $\begin{array}{l}\text { List O } \\
\text { tive } \\
\mathrm{C}-\mathrm{C} \\
\mathrm{C} \text { (C } \\
\text { grey }\end{array}$ & $\begin{array}{l}\text { abbre } \\
\text { spect } \\
\text { ontrol; } \\
\text { nscie } \\
\text { ells C }\end{array}$ & $\begin{array}{l}\text { viation } \\
\text { tions; } \\
\text { RA - } \\
\text { iousn } \\
\text { rrespo }\end{array}$ & $\begin{array}{l}\text { : LS - } \\
\text { JE - n } \\
\text { k acc } \\
\text { ss); N } \\
\text { nd to }\end{array}$ & $\begin{array}{l}\text { fe sa } \\
\text { gative } \\
\text { ptan } \\
\text { Neurc } \\
\text { leak, }\end{array}$ & $\begin{array}{l}\text { facti } \\
\text { expe } \\
\text { e, GR } \\
\text { icism) } \\
\text { noder }\end{array}$ & $\begin{array}{l}\text {; PA - } \\
\text { ations } \\
\text { gene } \\
\text { O lOp } \\
\text { te, an }\end{array}$ & $\begin{array}{l}\text { Dositiv } \\
\text { do - } \\
\text { nnesi } \\
\text { aver }\end{array}$ & $\begin{array}{l}\text { affe } \\
\text { ispos } \\
\text { nce; } \\
\text { o exp } \\
\text { ge co }\end{array}$ & $\begin{array}{l}\text {; NA } \\
\text { onal } \\
\text { (Extr } \\
\text { erienc } \\
\text { elatid }\end{array}$ & $\begin{array}{l}\text { ega } \\
\text { timisı } \\
\text { ersior } \\
\text {; }\end{array}$ & $\begin{array}{l}\text { /e aff } \\
; \text { I- in } \\
\text {; I } A\end{array}$ & $\begin{array}{l}\text { ct; } P E \\
\text { olvme } \\
\text { reeak }\end{array}$ & $\begin{array}{l}\text { posi- } \\
\text { ti; } \\
\text { eness }\end{array}$ & \\
\hline
\end{tabular}

Table 6. The results of the hypotheses validization test

\begin{tabular}{|c|c|c|}
\hline $\begin{array}{c}\text { Everyday life personal } \\
\text { problems scale }\end{array}$ & Direct correlation & Inverse correlation \\
\hline $\begin{array}{l}\text { a) the severety of } \\
\text { everyday life personal } \\
\text { problems } \\
\text { б) the degree of life } \\
\text { problematization }\end{array}$ & $\begin{array}{l}\text { - dispositional } \\
\text { pessimism } \\
\text { - neuroticism } \\
\text { - negative affect }\end{array}$ & $\begin{array}{l}\text { - resilience level - dispositional } \\
\text { optimism } \\
\text { - extraversion } \\
\text { - conscientiousness } \\
\text { - openness to experience } \\
\text { - agreeableness } \\
\text { - life satisfaction } \\
\text { - positive affect }\end{array}$ \\
\hline
\end{tabular}


The observed pattern of correlations adequately fits into the theoretical understanding of everyday personal problems, which is why the design of the questionnaire can be considered valid.

Differential validity of the questionnaire was proved by comparing its metrics with the personal characteristics measured by the NEO-PI-R questionnaire. It was assumed that weak or strong manifestation of a particular disposition becomes a triggering factor for occurrence of a specific class of personal problems.

The estimation of this type of validity was carried out using multiple regression by the method of backward stepwise analysis, aimed at highlighting the strongest predictor of the predetermined list of independent variables. Predictors were the factors of The "Big Five", the dependent variable was alternately assigned indicators of severity of classes of personal problems. The results are presented in Table 7.

Table 7. The results of the questionnaire's differential validity test

\begin{tabular}{|c|c|c|c|c|c|c|}
\hline \multirow{2}{*}{$\begin{array}{l}\text { Category of personal } \\
\text { problems }\end{array}$} & \multicolumn{5}{|c|}{ Predictors } & \multirow[t]{2}{*}{$\mathbf{R}^{2}$} \\
\hline & E & A & C & $\mathbf{N}$ & 0 & \\
\hline Problems of self-assertion & $-0,23^{* * *}$ & $0,39 * * *$ & & $0,25^{* * *}$ & & $0,19^{* * *}$ \\
\hline $\begin{array}{l}\text { Problems of time regula- } \\
\text { tion Проблемы регуля- } \\
\text { ции времени }\end{array}$ & & & $-0,52^{* * *}$ & $0,21^{* * *}$ & & $0,33^{* * *}$ \\
\hline $\begin{array}{l}\text { Problems of } \\
\text { self-consciousness }\end{array}$ & & & $-0,29 * * *$ & $0,26^{* * *}$ & $-0,17^{* * *}$ & $0,19^{* * *}$ \\
\hline Moral problems & & $-0,40 * * *$ & $-0,14^{* * *}$ & $0,19 * * *$ & & $0,25^{* * *}$ \\
\hline $\begin{array}{l}\text { Problems of S-P } \\
\text { adaptation }\end{array}$ & $-0,44^{* * *}$ & & & $0,22^{* * *}$ & & $0,25^{* * *}$ \\
\hline $\begin{array}{l}\text { Problems of coping and } \\
\text { self-regulation in DLS }\end{array}$ & $-0,18^{* * *}$ & & $-0,23^{* * *}$ & $0,52^{* * *}$ & & $0,40^{* * *}$ \\
\hline Cognitive problems & $-0,14^{* * *}$ & & $-0,22^{* * *}$ & & & $0,09^{* * *}$ \\
\hline \multicolumn{7}{|c|}{$\begin{array}{l}\text { Notes: } \\
\text { 1) list of abbreviations: E (Extraversion); A (Agreeableness); C (Conscientiousness); } \\
\mathrm{N} \text { (Neuroticism); O (Openness to experience); } \mathrm{R}^{2} \text { - multiple determination } \\
\text { coefficient; } \\
\text { 2) the numbers in the cells represent the values of standardized regression coef- } \\
\text { ficients }(\beta) ; \\
\text { 3) }{ }^{* * *} p<0,001\end{array}$} \\
\hline
\end{tabular}


The obtained results allow us to assert that the weak or strong expression of a personal characteristic determines the emergence of specific personal problems that reflect the psychological originality of this personal property. This general pattern gets its concrete expression in the fact that: 1) a low level of extroversion is indicative of the problem of socio-psychological (communicative) adaptation; 2) a low level of agreeableness/cooperation is indicative of a problem with moral self-regulation of personal behavior; 3 ) a high level of agreeableness/cooperation is indicative of a problem with self-assertion in interpersonal relations; 4) a low level of conscientiousness is indicative of a problem with life time regulation; 5) a high level of neuroticism-self-regulation is indicative of the problems with handling negative emotional states in difficult situations; 6) a high level of neuroticism is indicative of all the classes of personal problems, except for cognitive problems. The discovered selectivity of connections between personality traits and classes of personal problems testifies to the high differential validity of the developed technique.

The criteria validity of the questionnaire was tested using a sample of patients from Grodno State Clinical Hospital № 3 (see the description of the sample). The variety of criteria validity checked in this way can be concretized as a complex current validity, since the discrepancy with everyday life difficulties plays a significant role in the etiopathogenesis of borderline mental health disorders [26]. Evaluation of this validity was carried out by comparing the parameters of the questionnaire in contrast groups - population $(\mathrm{N}=506)$ and hospital $(\mathrm{N}=43)$ ones. The results of the comparative analysis of the Student's t-test for independent samples are given in Table 8.

Table $\mathbf{8}$. The results of the criteria validity test

\begin{tabular}{|l|c|c|c|c|c|c|}
\hline \multirow{2}{*}{$\begin{array}{l}\text { Points and values of the } \\
\text { questionnaire }\end{array}$} & \multicolumn{2}{|c|}{ Mean Value } & \multicolumn{2}{|c|}{$\begin{array}{c}\text { Standard } \\
\text { Deviation }\end{array}$} & $\begin{array}{c}\mathbf{t} \\
\mathbf{p}<\mathbf{0 , 0 0 1}\end{array}$ & Cohen`s d \\
\cline { 2 - 7 } & $\mathbf{P S}_{506}$ & $\mathbf{C S}_{\mathbf{4 3}}$ & $\mathbf{P S}_{506}$ & $\mathbf{C S}_{\mathbf{4 3}}$ & & \\
\hline $\begin{array}{l}\text { Problems of self- } \\
\text { assertion in interpersonal } \\
\text { relations }\end{array}$ & 15,66 & 23,70 & 4,18 & 5,34 & 11,82 & 1,68 \\
\hline $\begin{array}{l}\text { Problems of personal } \\
\text { regulation of the life } \\
\text { time }\end{array}$ & 21,70 & 33,53 & 5,56 & 3,76 & 13,70 & 2,49 \\
\hline $\begin{array}{l}\text { Problems of } \\
\text { self-consciousness }\end{array}$ & 12,79 & 19,60 & 3,36 & 3,86 & 12,60 & 1,88 \\
\hline $\begin{array}{l}\text { Moral problems of } \\
\text { personality }\end{array}$ & 15,31 & 24,05 & 3,65 & 3,68 & 15,07 & 2,39 \\
\hline
\end{tabular}




\begin{tabular}{|c|c|c|c|c|c|c|}
\hline \multirow[t]{2}{*}{$\begin{array}{l}\text { Points and values of the } \\
\text { questionnaire }\end{array}$} & \multicolumn{2}{|c|}{ Mean Value } & \multicolumn{2}{|c|}{$\begin{array}{l}\text { Standard } \\
\text { Deviation }\end{array}$} & \multirow[t]{2}{*}{$\begin{array}{c}t \\
p<0,001\end{array}$} & \multirow[t]{2}{*}{ Cohen's d } \\
\hline & $\mathrm{PS}_{506}$ & $\mathrm{CS}_{43}$ & $\mathrm{PS}_{506}$ & $\mathrm{CS}_{43}$ & & \\
\hline $\begin{array}{l}\text { Problems of socio- } \\
\text { psychological } \\
\text { adaptation of } \\
\text { personality }\end{array}$ & 6,93 & 11,47 & 2,51 & 3,11 & 11,14 & 1,60 \\
\hline $\begin{array}{l}\text { Problems of coping and } \\
\text { self-regulation in difficult } \\
\text { life situations }\end{array}$ & 21,36 & 32,16 & 5,32 & 4,85 & 12,86 & 2,12 \\
\hline $\begin{array}{l}\text { Cognitive problems of } \\
\text { the personality }\end{array}$ & 7,35 & 10,63 & 2,27 & 2,07 & 9,13 & 1,51 \\
\hline $\begin{array}{l}\text { General level of } \\
\text { problematization of } \\
\text { everyday life }\end{array}$ & 101,11 & 155,14 & 19,18 & 12,87 & 18,12 & 3,31 \\
\hline \multicolumn{7}{|c|}{$\begin{array}{l}\text { Notes: } \\
\text { 1) list of symbols: } \mathrm{PS}_{506} \text { - population sample of } 506 \text { individuals; } \mathrm{CS}_{43} \text { - clinical sample } \\
\text { of } 43 \text { individuals; } \dagger \text { - empirical value of Student's criterion for independent groups; } \\
\text { Cohen`s } d \text { - extent of Cohen's d effect }\end{array}$} \\
\hline
\end{tabular}

The data show significant differences between the groups: compared to the respondents in a state of relative norm, people with borderline mental disorders: 1) give higher estimation of the subjective difficulty in solving all types of the daily problems without exception; 2) have a higher level of expression of all the identified types of personal problems; 3 ) are prone to significant problematization of their daily activities as a whole.

The obtained results prove the criteria validity of both separate tasks (points) of the questionnaire and its final diagnostic assessment. Also, the data speak in favor of the current and prognostic validity of the questionnaire and allow to recommend it for additional confirmation of clinical diagnosis and prognosis.

\section{Diagnostic norms}

Diagnostic norms were created taking into account the nature of the distribution of the test results of the standardization sample. The data in Table 9 indicate that the distribution of primary scores on the sub-scales and on the integral scale of the questionnaire deviates significantly from the normal distribution. Deviation from normality is evidenced by the high estimated values of the Komogorov-Smirnov criterion as well as the values of asymmetry, 
which greatly exceeds the magnitude of the standard errors $(0,10)$. The positive values of the asymmetry index and the quantitative ratio of the central trend indicators (mode < median < average) allow us to clame that the general pattern of distribution of raw scores on the partial and composite indicators of the questionnaire is expressed in the right-hand shift, i.e. the shift to the low values. It should be noted that the right-hand shift of distributions in our case was predictable, since this kind of asymmetry of test results is typical for the whole family of self-report techniques that diagnose everyday personality-related problems and daily stressors. This is probably due to the fact that the stimulus material in these techniques is represented by ordinary problems and events (as opposed to methods that evaluate the perception and response to extreme and extraordinary situations). Because of their habitual character, everyday problems are more feasible for respondents, which is reflected in the relatively low estimates of the subjective difficulty of solving and overcoming them.

Table 9. Descriptive statistics of the distribution of test results in the standardization sample

\begin{tabular}{|c|c|c|c|c|c|c|c|}
\hline Areas of questioning & $M$ & $\mathrm{Me}$ & Mo & [min; max] & $\sigma$ & Asymmetry & MaxD \\
\hline $\begin{array}{l}\text { Problems of } \\
\text { self-assertion }\end{array}$ & 16,29 & 16 & 13 & {$[9 ; 34]$} & 4,79 & 0,85 & $0,09 * *$ \\
\hline $\begin{array}{l}\text { Problems of time } \\
\text { regulation }\end{array}$ & 22,62 & 22 & 21 & {$[12 ; 42]$} & 6,29 & 0,55 & $0,08^{* *}$ \\
\hline $\begin{array}{l}\text { Problems of } \\
\text { self-consciousness }\end{array}$ & 13,33 & 13 & 12 & {$[8 ; 26]$} & 3,86 & 0,75 & $0,12^{* *}$ \\
\hline Moral problems & 15,99 & 15 & 12 & {$[10 ; 34]$} & 4,33 & 0,86 & $0,11^{* *}$ \\
\hline $\begin{array}{l}\text { Problems of SP } \\
\text { adaptation }\end{array}$ & 7,29 & 7 & 4 & {$[4 ; 16]$} & 2,83 & 0,85 & $0,13^{* *}$ \\
\hline $\begin{array}{l}\text { Problems of coping } \\
\text { and self-regulation } \\
\text { in DLS }\end{array}$ & 20,24 & 20 & 16 & {$[10 ; 40]$} & 5,54 & 0,51 & $0,06^{*}$ \\
\hline Cognitive problems & 7,50 & 7 & 7 & {$[4 ; 14]$} & 2,22 & 0,48 & $0,15^{* *}$ \\
\hline Total score & 103,27 & 100 & 84 & {$[57 ; 214]$} & 23,14 & 0,64 & $0,05^{*}$ \\
\hline Notes: & \multicolumn{7}{|c|}{$\begin{array}{l}\text { 1) list of symbols: } M \text { - arithmetic mean; Me - me- } \\
\text { dian; Mo - mode; min - minimal value in the sample; } \\
\text { max - maximal value in the sample; } \sigma \text { - standard de- } \\
\text { viation; MaxD - empirical value of Kolmogorov-Smirnov } \\
\text { criterion; } \\
\text { 2) * } p<0,05 ; * *<<0,01\end{array}$} \\
\hline
\end{tabular}


Taking into account the form of empirical distribution of test results and the low severity of gender and age differences in them, diagnostic norms were determined based on the analysis of the frequency distribution of raw scores in the standardization sample and were considered as common for men and women in adolescence and adulthood. We used a quintile scale, which involves dividing a number of test values into five intervals (quintiles), which correspond to different levels of severity of the diagnosed characteristic: very low (1-20 percentile), low (21-40 percentile), medium (41-60 percentile), high (61-80 percentile) and very high (81-100 percentile). Table 10 shows the diagnostic norms constructed in this way for the "Scale of everyday personal problems" are shown in Table 10.

Table 10. Diagnostic norms (in raw scores)

\begin{tabular}{|l|c|c|c|c|c|}
\hline \multirow{2}{*}{ Indicators of the tool } & \multicolumn{4}{|c|}{ The degree of expression of the diagnostic sign } \\
\cline { 2 - 6 } & Very low & Low & Average & High & $\begin{array}{c}\text { Very } \\
\text { high }\end{array}$ \\
\hline Problems of self-assertion & $9-12$ & $13-14$ & $15-17$ & $18-20$ & $21-36$ \\
\hline Problems of time regulation & $12-17$ & $18-21$ & $22-23$ & $24-28$ & $29-48$ \\
\hline $\begin{array}{l}\text { Problems of } \\
\text { self-consciousness }\end{array}$ & $8-10$ & $11-12$ & $13-14$ & $15-17$ & $18-32$ \\
\hline Moral problems & $10-12$ & $13-14$ & $15-17$ & $18-19$ & $20-40$ \\
\hline Problems of SP adaptation & $4-5$ & 6 & $7-8$ & $9-10$ & $11-16$ \\
\hline $\begin{array}{l}\text { Problems of coping and } \\
\text { self-regulation in DLS }\end{array}$ & $10-15$ & $16-18$ & $19-21$ & $22-25$ & $26-40$ \\
\hline Cognitive problems & $4-5$ & 6 & 7 & $8-10$ & $11-16$ \\
\hline Total score & $57-83$ & $84-95$ & $96-107$ & $108-121$ & $122-228$ \\
\hline
\end{tabular}

\section{Conclusion}

The work resulted in creation of the original tool for Russian-speakers designed to diagnose the individual severity of everyday personal problems of the subject. The tool represents a multi-dimensional standardized questionnaire and has the appropriate measuring properties - high reliability, as well as the necessary criterial, structural, convergent and differential validity. The current version of the questionnaire can be recommended for use for scientific purposes: collecting empirical material in research on personality psychology, social psychology, psychology of coping behavior and other subject areas; for practical purposes as an additional assessment method in the process of psychological counseling, correction, prevention and therapy, including the clinical setting. The prospects of 
further psychometric development may lie in the definition of the retest reliability of the questionnaire and the assessment of the impact of social desirability on the results, as well as in the clarification and differentiation of test standards on the material taken from larger-scale population and clinical samples.

\section{References}

1. Asmolov A. G. Psychology of modernity: Challenges of uncertainty, complexity and diversity. Psychological Studies, 2015, Vol. 8, no. 40, p. 1. Available at: http://psystudy.ru (Accessed 05 September 2018).

2. Gusel'tseva M. S. Everyday life psychology: methodology, history and perspectives. Psychological Studies, 2017, Vol. 10, no. 51, p. 12. Available at: http://psystudy.ru (Accessed 05 September 2018).

3. Martsinkovskaya T. D. Modern psychology: Challenges of transitivity. Psychological Studies, 2015, Vol. 8, no. 42, p. 1. Available at: http://psystudy.ru (Accessed 05 September 2018).

4. Costa P.T., Jr., Widiger T. A. (eds.) Personality disorders and five-factor model of personality. Washington, DC: American Psychological Association, 2002. $493 \mathrm{p}$.

5. Piedmont R. L., Sherman M. F., Sherman N. C., Dy-Liacco G. S., Williams J. E. Using the five-factor model to identify a new personality disorder domain: the case for experiential permeability. Journal of Personal Social Psychology, 2009, Vol. 96, pp. 1245-1258.

6. Pincus A. L., Wiggins J. S. Interpersonal Problems and Conceptions of Personality Disorders. Journal of Personality Disorders, 1990, Vol. 4, no. 4, pp. 342-352.

7. Widiger T. A., Costa P. T., Jr., McCrae R. R. A proposal for Axis II: Diagnosing personality disorders using the five-factor model. In: P. T. Costa, Jr., T. A. Widiger (eds.) Personality disorders and the five-factor model of personality. Washington, DC, US: American Psychological Association, 2002, pp. 431-456.

8. Widiger T. A., Mullins-Sweatt S. N. Clinical utility of a dimensional model of personality disorder. Professional Psychology: Research and Practice, 2010, Vol. 41 (6), pp. 488-494.

9. McCrae R. R., Lockenhoff C. E., Costa P.T. A step toward DSM-V: cataloguing personality related problems in living. European Journal of Personality, 2005, Vol. 19 (4), pp. 269-286.

10. Ozer D. J., Benet-Martínez V. Personality and the prediction of consequential outcomes. Annual Review of Psychology, 2006, Vol. 57, pp. 401-421.

11. Piedmont R. L., Sherman M. F., Barrickman L. Brief psychosocial assessment of a clinical sample: an evaluation of the Personal Problems Checklist for Adults. Assessment, 2000, Vol. 7 (2), pp. 177-187.

12. Boudreaux M. J. Personality-related problems and the five-factor model of personality. Personal Disorders, 2016, Vol. 7(4), pp. 372-383. 
13. Boudreaux M. J., Piedmont R. L., Sherman M. F., Ozer D. J. Identifying personality-related problems in living: The Multi-Context Problems Checklist. Journal of Personality Assessment, 2013, Vol. 95 (1), pp. 62-73. DOI: $10.1080 / 00223891.2012 .717149$

14. Schinka J. A. Children's Problems Checklist. NY: Psychological Assessment Resources, 1985.

15. Horowitz L. M., Rosenberg S. E., Baer B. A., Ureno G., Villasenor V. S. Inventory of interpersonal problems: Psychometric properties and clinical applications. Journal of Consulting and Clinical Psychology, 1988, Vol. 56, pp. 885-892.

16. Osin E. N., Leont'ev D. A. Aprobatsiya russkoyazychnyi versii dvukh shkal ekspress-otsenki sub"ektivnogo blagopoluchiya [Testing of Russian versions of the two scales of a rapid assessment of subjective well-being]. Materialy III Vserossiiskogo sotsiologicheskogo kongressa [Proc. the 3rd All-Russian Sociological Congress]. Moscow, Institute of Sociology RAS Publ., 2008.

17. Osin E. N. Measuring positive and negative affect: Development of a Russian-language analogue of PANAS. Psikhologiya. Zhurnal Vysshei shkoly ekonomiki - Psychology. Journal of the Higher School of Economics, 2012, Vol. 9, no. 4, pp. 91-110 (in Russian).

18. Khromov A. B. Pyatifaktornyi oprosnik lichnosti [Five-factor personality questionnaire]. Kurgan, Kurgan State University Publ., 2000. 23 p.

19. Gordeeva T. O., Sychev O. A., Osin E. N. Development of the Russian-language version of the test of dispositional optimism (LOT). Psikhologicheskaya diagnostika - Psychological Diagnostics, 2010, no. 2, pp. 36-64 (in Russian).

20. Leont'ev D. A., Rasskazova E. I. Test zhiznestoikosti [Resilience test]. Moscow, Smysl Publ., 2006. 63 p.

21. Costa P.T., Jr., McCrae R. R. Personality Disorders and The Five-Factor Model of Personality. Journal of Personality Disorders, 1990, Vol. 4 (4), pp. 362-371. DOI: $10.1521 /$ pedi.1990.4.4.362

22. Maddi S. R. Hardiness: The courage to grow from stresses. Journal of Positive Psychology, 2006, Vol. 1(3), pp. 160-168. DOI: 10.1080/17439760600619609

23. Emmons R. The psychology of ultimate concerns: Motivation and spirituality in personality (Russ. ed.: Emmons R. Psikhologiya vysshikh ustremlenii: motivatsiya i dukhovnost' lichnosti. Moscow, Smysl Publ., 2004. 416 p.).

24. Diener E. Subjective well-being. Psychological Bulletin, 1984, no. 95 (3), pp. 542-575. DOI: 10.1037/0033-2909.95.3.542

25. Diener E., Emmons R. A., Larsen R. J., Griffin S. The Satisfaction with Life Scale. Journal of Personality Assessment, 1985, Vol. 49, pp. 71-75.

26. Aleksandrovskii Yu. A. Pogranichnye psikhicheskie rasstroistva [Borderline mental disorders]. Moscow, Meditsina Publ., 2000. 301 p. 